\title{
THE EFFECTS OF PERSONALITY TRAITS ON FINANCIAL BEHAVIOUR
}

\author{
DOI: 10.17261/Pressacademia.2019.1122 \\ JBEF-V.8-ISS.3-2019(2)-p.155-164
}

\section{Gokhan Ozer ${ }^{1}$, Ummuhan Mutlu²}

${ }^{1}$ Gebze Teknik University, Gebze, Kocaeli, Turkey. gokozerhan@gmail.com , ORCID: 0000-0002-3255-998X

${ }^{2}$ Kocaeli University, Izmit, Kocaeli, Turkey. ummuhan.mutlu@kocaeli.edu.tr, ORCID: 0000-0002-6277-228X

\begin{abstract}
Purpose- The development of financial markets, the complexity of financial products and services, the differences in individual invest or profile increase the importance of estimating the financial behaviour of individual investors. The aim of the study is to determine the effects of individual investor's personality traits on their financial behaviors.

Methodology- A questionnaire designed to evaluate the personality traits and financial behaviours of individual investors was used. The data set consisted of 1347 individual investors through survey method. We performed multiple linear regression to examine the hypothesized relationships.

Findings- According to the statistical results of the research, the dimensions of personality traits such as conscientiousness, agreeableness and openness to experience have positive and significant effects on financial behaviour. But extraversion and neuroticism have not significant effects on financial behaviour.

Conclusion- The results of the study emphasize the importance of personality characteristics in explaining financial behaviours. Personality traits are important factors that financial institutions should focus on when offering products and services related to individual investor portfolios.
\end{abstract}

Keywords: Behavioral finance, financial behaviour, personality traits, financial risk tolerance, financial literacy. JEL Codes: G00, G40, G41

\section{INTRODUCTION}

Financial behaviour can be defined as the expenditure, saving, investment and planning actions of the individual in the financial fields. The development of financial markets, differences in investor profile and complexity of financial products increase the importance of estimating the financial behaviour of individual investors. Financial behavior, which is the focus of interest of researchers for the reasons stated, has attracted interest from both microeconomic and macroeconomic aspects by researchers and policy makers. Financial attitudes and behaviours have an effect on financial decisions on monetary issues such as expenditure, saving, budgeting and investment. Financial decisions of individuals are effective on financial welfare levels. In order to make the right decisions on the management of money, such as the evaluation of investments in the right investment tools, spending and savings, it is necessary for individuals to increase their financial literacy levels and evaluate their decisions in terms of risk, return and cost. Many studies based on classical finance theory have used demographic and socio-economic factors to explain financial behavior (e.g., Bajtelsmit and Bernasek, 1996; Powel and Ansic, 1997; Wang and Hanna, 1997; Grable and Lytton,1998; Dwyer et al., 2002; Hallahan et al., 2004; Grable and Joo, 2004; Roszkowski and Grable, 2005; Jianakoplos and Bernasek, 2006; Anbar and Eker, 2010; Gong and Yang, 2012; Larkin et al., 2013; Lan et al., 2018). The inadequacy of classical finance in explaining the financial problems and market anomalies faced by individuals caused new theories to emerge. Developed behavioural finance models against the effective market hypothesis argue that individuals are not fully rational and subject to some psychological tendencies while making decisions on financial matters. For this reason, 
not only economic reasons but also psychological and sociological factors should be taken into consideration when examining individuals' financial attitudes and behaviours.

There are many internal and external factors affecting the financial behaviour of individuals. One of the internal factors that influence financial behaviour is personality. Personality is a relatively permanent form of individual thoughts, emotions, motives and behaviours (McCrae and John, 1992). Several dimensions related to personality have been revealed by the researchers. Goldberg (1990) stated that five strong factors emerged in his study based on adjectives in the dictionary and suggested that personality research could be organized within the framework of these five strong factors.

Personality traits are one of the important psychological factors affecting the financial behavior of individual investors. Individual investors may be considered as investors who are trading in financial areas on their own behalf. Unlike institutional investors, individual investors may be more affected by psychological and sociological factors. This research focuses on the effect of personality traits in determining investor behaviour that rational models do not provide sufficient explanations under the behavioural finance perspective. The paper contains sections suitable for scientific flow. The review of the relevant literature is provided in the second section. The third section includes data and methodology. In the fourth section, findings and discussions are given. The last section indicates the conclusion and recommendations.

\section{LITERATURE REVIEW}

\subsection{Financial Behaviour}

Financial behaviour, in the most basic sense, can be thought of as monitoring individuals' financial conditions, making careful purchases, managing their loans, savings and investments (Alkaya and Yagli, 2015). Hilgert, Hogarth, and Beverly (2006) divide financial behaviour into four basic sub-factors; cash management, credit management, savings and investment. The findings of the study characterize financial behaviors as hierarchical. The types of financial products owned by individuals can provide information on how well they manage their personal financial resources and how financially responsible and forward-looking. This conclusion is consistent with other studies show that budgeting, controlling expenditure and forward thinking are indicators of responsible financial behavior for specific actions (Perry and Morris, 2005). The effects of factors such as financial information, locus of control and income are examined on individual behavior. As a result, financial knowledge and locus of control have a significant effect on financial behavior, while income does not have the same effect (Arifin, 2017). There are studies suggesting that financial information acquired at an early age may affect subsequent financial behaviour. Kotlikoff and Bernheim (2001) investigated a sample of consumers in the highest earning periods (30-49 years) and showed that adults attending private financial education schools caused more financial behaviours towards non-educated adults. Kubilay et al.,(2016) examined the personality traits, psychological tendencies and financial risk tolerance of the individual investor. It was stated that there was a significant relationship between the personality traits and psychological tendencies of the investors and the personal characteristics affect the financial risk tolerance. Financial literacy is a concept beyond financial information, which is defined as the development of financial consciousness and understanding of financial concepts and procedures (Potrich et al., 2016). Lusardi's study (2008) examined the saving behaviour of American households and report that the effect of the low financial literacy and lack of education on savings behaviour. Financial education programs and financial advice are not only for individuals' savings for retirement but also suggests that children will be able to increase their special savings, which will help them against the suddenly loss of their education or income.

\subsection{Personality Traits}

Personality can be defined as one of the fundamental psychological factors that shape human behaviour. Personality is taken partly genetically inherited from parents (Raheja and Dhiman, 2017). However, many factors such as social environment, family, geographical and physical conditions can be effective in personality development. For this reason, it can be said that individuals have different personality traits which are one of the main reasons for developing different perceptions or solutions against the same events (Erkuş and Tabak, 2009). Goldberg (1990) stated that five powerful personality traits called the"big five" emerged and personality researches could be organized within the framework of these five strong factors. Accordingly, the first dimension of the five personality model is extraversion. The extravert people are more social, more active and impulsive, less dysphoric, less introspective and self-preoccupied with ones compared to inward individuals (Watson and Clark, 1997). The second dimension of the model is agreeableness. Agreeableness includes many aspects such as socially preferred trust, forgiveness, helpfulness, and friendlyness. Disagreable individuals are more skeptical, self-centered and cruel (Costa and McCrae, 1992). Conscientiousness which is the third dimension of the five factor personality model, can be defined as diligent, responsible and careful, planned and organized. It is also associated with success, order and persistence as well as the degree of self-control (Costa, McCrae, and Dye, 1991). According to Costa and McCrae (1992b), the fourth dimension of neuroticism is examined in six sub-aspects: anxiety, hostility, depression, self-consciousness, vulnerability and impulsivity. Individuals with a high score of neuroticism probably have a variety of problems, including negative moods and 
physical symptoms. The final dimension of the model is openness to experience. It is about creativity, imagination and innovation(Zhao and Seibert, 2006). Individuals who are not open to experience are generally more narrow-minded and traditional. Choosing a new experience can be seen as a cognitive stimulus as it involves taking risks(McCrae and Costa, 1997). Although personality is generally associated with attitudes and behaviours, a limited number of studies focus on the effect of personality on financial issues. Davey and George (2011) examined the effects of personality traits on financial attitudes and behaviours and it is stated that conscientiousness and extraversion affected their savings and borrowing behaviours more than others. In line with expectations, conscientiousness and locus of control is found to have a profound effect on both financial attitude and behaviour. Agreeableness, openness to experience and neuroticism were also important, while extroversion was shown to affect normal saving behaviours. Oehler et al. (2017) analyzed the effects of extraversion and neuroticism degrees on decision making processes in the experimental asset market. The authors found that extraversion and neuroticism significantly affected individuals' behaviours in the experimental entity market. Less extroverted individuals buy less assets and pay lower prices for financial assets. Less neurotic individuals have more risky assets in their financial portfolios than more neurotic individuals. According to Tauni et al.(2017), which examined whether the personality traits of the individual investor affect the relationship between knowledge acquisition and stock trading behaviour, it showed that personality traits direct the relationship between buying and selling behaviours of stocks. This research confirms that traders who obtain more information are more likely to trade in stocks. The acquisition of information tends to increase the trading frequency of investors who have conscientiousness, extraversion, and agreeableness personality traits. The individuals who have different personality characteristics also have different financial risk tolerance levels and these different personal properties ultimately affect the financial behaviour in the form of different savings and savings amounts. This key finding promotes the more study of psychological factors between financial risk tolerance and financial behaviour (Pinjisakikool, 2018). When the studies investigated the relationship between personality and financial risk tolerance, it was stated that there was significant relationship between personality traits such as extraversion and openness to experience, and other personality traits in which there is no positive relationship with financial risk tolerance (Pak and Mahmood, 2015). Soane et al. (2010) found that personality affects choice behavior both directly and through perceived costs and benefits.

\subsection{Hypotesis Development and the Research Model}

In general, researchers defined the significance of five dimensions to separate individuals into definite personality classifications (Digman, 1990). The five dimensions of the Big Five Model classify extraversion, agreeableness, conscientiousness, openness to experience and neuroticism. Different results have been obtained from the studies investigating the relationship between personality traits of the individual investor and its financial behaviour. As a result of the literature research and previous experimental researches, the research model developed to estimate the impacts of individual investors' personality traits on their financial behaviour as shown in figure 1.

\section{Figure 1: Research Model}

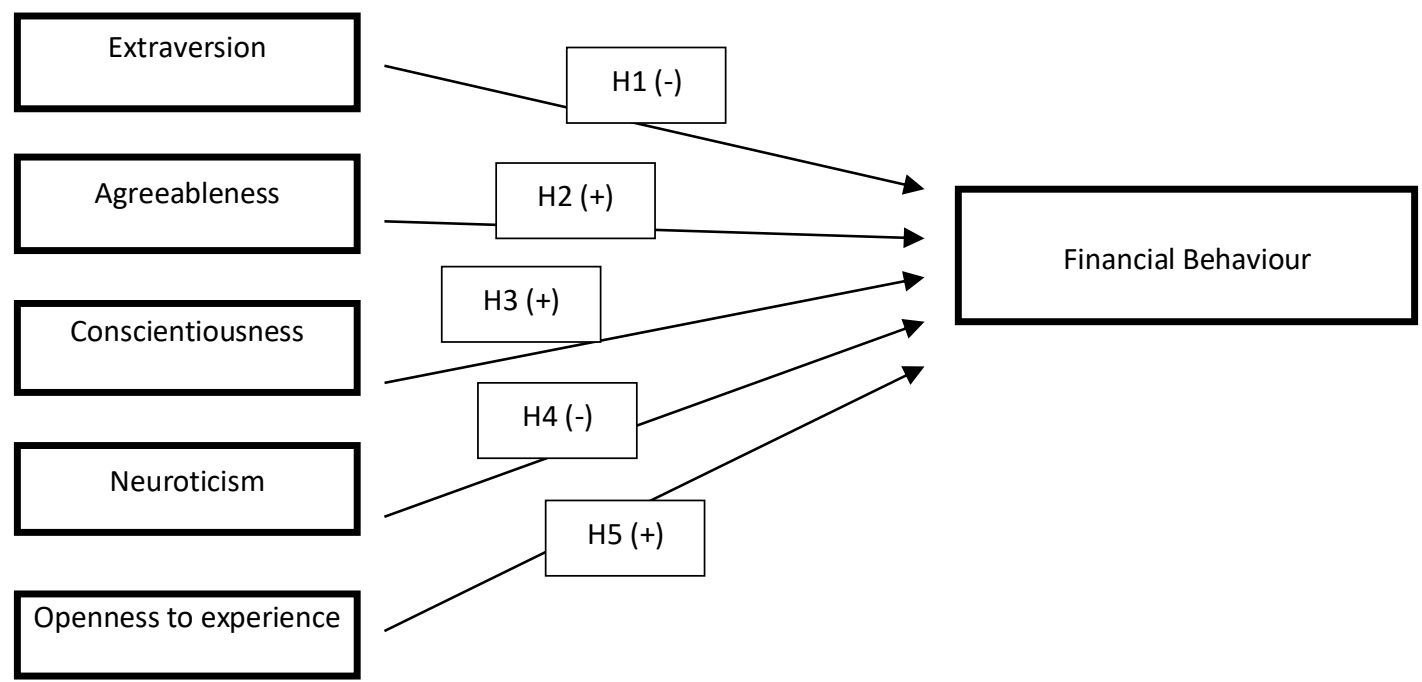


The hypothesis of the study was developed by taking into consideration the characteristics of the big five personality traits. The extraversion personality dimension represents the level of sociality and affinity of the individual. The basic characteristics of extraversion are more prone to experience warmth, initiative, aggressiveness, excitement and positive emotions. Extraverts tend to be risk averse and continue holding losing stocks with the hope of revival (Jamshidinavid et al.2012). Zaidi and Tauni (2012) studied the individual investors to detect the relation among overconfidence bias, demographics and personality traits. According to the results of the study, extraversion with overconfidence bias is positively related. On the other hand, Asebedo (2018), investigating the relationship between personality traits and financial behaviour, found the relationship between extraversion and financial behaviour negative. We anticipate that extraversion personality dimension affects the financial behavior of the individual investor negatively. Thus we hypothesize that;

H1: The extraversion negatively affects the financial behaviour of the individual investor.

The agreeableness personality dimension is more related to interpersonal relationships and it is close, social and trustworthy against other individuals. Nga and Yien (2013), found that conscientiousness, openness and agreeableness have a significant influence on risk aversion. According to Davey and George (2011), financial attitudes with agreeableness seems to have a significant relationship with financial behaviour. So the next hypothesis is;

$\mathrm{H} 2$ : The agreeableness positively affects the financial behaviour of the individual investor.

The dimension of conscientiousness refers to individuals' planning, attention and degree of self-control exhibited. The study investigating the relationship between personality traits and financial behaviour, determined the relationship between conscientiousness and financial behaviour positive (Asebedo, 2018). According to Donnelly et al. (2012), conscientious individuals are successful in managing their money and financial attitudes and conscientious individuals have positive retirement planning and savings behaviour. (Hershey Openness to experience Mowen 2000), Hence the next hypothesis is;

H3: The conscientiousness positively affects the financial behaviour of the individual investor.

Neuroticism refers to whether the individual has an emotional balance. The neurotics tend to experience negative emotions such as emotional imbalance, anxiety, depression and anger. Mayfield et al. (2008) found that individuals with this personality trait had a propensity to avoid short term investing. Accordingly the next hypothesis is;

H4: The neuroticism negatively affects the financial behaviour of the individual investor.

Openness to experience represents the tendency to participate in intellectual activities and to be open to new feelings and thoughts. Mayfield et al. (2008) found that individuals with this personality trait had the propensity to engage in long term investing. Openness have a strong relationship with risk taking (Kowert and Hermann, 1997). In the view of these researches, we expect that openness personality dimension affects the financial behaviour of the individual investor positively. So we hypothesize that;

H5: The openness to experience positively affects the financial behaviour of the individual investor.

\section{DATA AND METHODOLOGY}

The focus of this study is to measure the effect of personality traits on the financial behaviour of individual investors. In this study, the scale of personality inventory developed by Goldberg (1990) was modified and then used to measure in order to measure five factor personality types. The personality traits scale was grouped under five factors and consisted of 35 items. Financial behaviour scale which developed by Potric, Ani, Caroline Grigion, Kelmara Mendes Vieira, and Weesley Mendes-DaSilva (2016) was modified and consisted of 9 items. Because of these scale changes, we conducted an exploratory factor analysis to see to what extent these items would be accumulated in the same factors.

In this study, the research data were collected through a questionnaire and the financial behavior of individual investors was measured. The hand questionnaires were delivered to banks, government agencies, hospitals, schools and private or state universities. Two pilot studies were fulfilled. In the first one, consisting of 154 participants, was comprised on academicians and teachers in Kocaeli, i̇stanbul and Bursa in Turkey. The second pilot study was conducted with 52 officers and academicians from Istanbul and Kocaeli. These pilot studies aimed to examine the factor structures of the variables.

In the original study, sample consisted of 1347 individual investors over the age of 18 and selected according to the random sampling method. Sampling was constituted from certain major cities in Turkey, including Istanbul, Kocaeli, Ankara, Izmir, Bursa and Karabuk. Participants were chosen among academicians, businessmen, managers, university employees, teachers, officers, public-private sector employees and retired people. We did not include participants if they are under 18 ages and financially depend. Sampling descriptive statistics showed that 43,5 percent of the participants were female and (44 percent) were bachelor's degree and 25-50 age range. Nearly, 66 percent of the participants are married and 34 percent are single. 
The income level of the participants is 4000 Turkish Liras (12,5 percent) and 5000 Turkish Liras(15 percent). The questionnaire consisted of 5-point Likert scale questions to measure the participants' personality traits and their thoughts on financial behaviour. Kaiser-Meyer-Olkin and Bartlett Tests were conducted to decide the suitableness of the scale for factor analysis before explanatory factor analysis. Before the explanatory factor analysis, tests were conducted to determine the suitability of the scale for factor analysis. Kaiser-Meyer-Olkin (KMO) value, which shows whether the factor analysis is adequate and whether the sample is sufficient for analysis, was obtained as 0.932 . In this study, principal component analysis revealed no restriction on the number of factors and a total of 6 factors appeared. As a result of the analyzes made in this scope, the factor structure seen in appendix 1 has emerged. Factor loadings of the items formed using Promax rotation method and Cronbach's alpha values of factors in the analysis are shown in Appendix 1. The means, the standard deviations and the correlations of the variables can be seen in Table 1. As seen the the pearson correlation coefficients in Table 1, all variables except the neuroticism have significant relationships with each other at the level of $p<0.05$ and $p<0.01$. Considering these coefficients, the conscientiousness relationship with financial behaviour is higher than the relationship with other categories.

\section{Table 1: Correlations}

\begin{tabular}{|c|c|c|c|c|c|c|c|c|}
\hline Variables & Mean & S.D. & 1 & 2 & 3 & 4 & 5 & 6 \\
\hline $\begin{array}{l}\text { 1.Financial } \\
\text { Behaviour }\end{array}$ & 3,8490 & 74294 & 1 & $352^{* *}$ & ,439** & $307^{* *}$ & ,174** & ,000 \\
\hline 2.Agreeableness & 3,8942 & ,66853 & ,352** & 1 & ,654** &, $430 * *$ & ,276** &,$- 115^{* *}$ \\
\hline 3.Conscientiousness & 4,0415 & 72746 & ,439** & ,654** & 1 &, $547^{* *}$ &, $232 * *$ &,$- 054 *$ \\
\hline 4.Openness & 3,7702 & ,78210 & ,307** & ,430** &, $547^{* *}$ & 1 &, $384 * *$ &,- 042 \\
\hline 5.Extraversion & 3,2750 & ,70992 &, $174 * *$ & ,276** & ,232** & ,384** & 1 &,$- 143 * *$ \\
\hline 6. Neuroticism & 2,8957 & 85269 &, 000 &,$- 115^{* *}$ &,$- 054 *$ &,- 042 &,$- 143^{* *}$ & 1 \\
\hline
\end{tabular}

\section{FINDINGS AND DISCUSSIONS}

In order to test the hypotheses multiple linear regression analysis was used through IBM SPSS Statistics 21 . The regression equation, in which the effect of individual investor's personality traits on financial behaviour, was found to be statistically significant $(F=70,610 ; p<, 000)$. According to table 2, for the significance of the independent variable, it can be stated that the t-test is significant at level $p<0.05$ for the conscientiousness $(\beta=, 328 ; p<, 000)$, agreeableness $(\beta=, 099 ; p<, 003)$ and openness to experience $(\beta=, 068 ; p<, 027)$. Neuroticism and extroversion were not significant at level $p<0.05$ significance level. These findings required acceptance of hypotesis 2 "The agreeableness positively affects the financial behaviour of the individual investor", hypotesis 3 "The conscientiousness positively affects the financial behaviour of the individual investor" and hypotesis 5 "The openness to experience positively affects the financial behaviour of the individual investor". These findings also require the rejection of hypotesis 1 "The extraversion positively affects the financial behaviour of the individual investor" and hypotesis 4 "The neuroticism positively affects the financial behaviour of the individual investor".

This means that the conscientiousness, agreeableness and, openness to experience personality traits have positive impact on the financial behaviour of the individual investor. According to the results of the analysis neuroticism and extraversion personality characteristics have no effect on financial behaviour. The beta coefficients of significant variables are 0.328 (conscientiousness), 0.099 (agreeableness) and 0.068 (openness to experience). The highest coefficient value is the conscientiousness which shows that it is one of the most crucial determinants of financial behaviour. The one-unit increase in conscientiousness leads to a positive change of 0.328 points against financial behaviour.

In this study, the effect of individual investor's personality traits on financial behaviour was analyzed by regression analysis of the data obtained from 1347 investors. According to the findings of the analysis; the personality dimensions of conscientiousness, agreeableness and openness to experience on the financial behaviour of the individual investor have a statistically significant effect. However, extraversion and neuroticism have no significant effect on the individual investor's financial behaviour. This result is consistent with the results of many studies (Donnely et al., 2012, Nga and Yien, 2013; Asebedo, 2018) in the literature. On the contrary, there are studies suggesting different results. For example, the studies on the effect of extraversion and neuroticism degrees on decision making processes in the experimental asset market and on financial risk tolerance, the authors found significant effects (Oehler et al., 2017); (Pak and Mahmood, 2015). Pinjisakikool (2018) stated that encourages further study of the psychological factors between financial risk tolerance and financial behaviour. The research are revealed that individuals with different personality traits have different levels of financial risk tolerance and these different personal characteristics ultimately affect financial behaviour in the form of different savings 
and savings amounts (Pinjisakikool, 2018). Conscientiousness, agreeableness and openness to experience simultaneously affect the financial behaviour in a statistically significant and positive way, but the beta coefficients are different. Conscientiousness $(\beta=, 328)$ has more effect than the other two dimensions. This finding supports many studies in the literature(Donnely et al., 2012; Asebedo,2018; Asebedo et al., 2019).

Table 2: Results of Regression

\begin{tabular}{|l|c|c|c|}
\hline \multicolumn{3}{|c|}{ Financial Behaviour } \\
\hline Independent Variables & Beta & $\mathbf{t}$ & $\mathbf{p}$ \\
\hline Extraversion &, 050 & 1,871 &, 062 \\
\hline Openness to experience &, 068 & 2,210 &, 027 \\
\hline Conscientiousness &, 328 & 9,393 &, 000 \\
\hline Agreeableness &, 099 & 3,014 &, 111 \\
\hline Neuroticism &, 039 & 1,596 &, 000 \\
\hline F & \multicolumn{2}{|c|}{70,610} &, 208 \\
\hline R Square & \multicolumn{3}{|l|}{, 205} \\
\hline Adjusted R Square & \multicolumn{2}{|l|}{} \\
\hline
\end{tabular}

\section{CONCLUSION}

Attitudes and behaviours related to financial issues have a significant impact on the financial well-being of individuals. In order to make the right financial decisions, it is important that individual investors have all the information they may need in financial matters, and that financial institutions should guide to investors about correct financial behaviour. Individual investors often receive support from financial institutions in creating their investment portfolios. When conducting consultancy services for financial institutions, they should create a special portfolio for the investor in line with the expectations of the individual investor. In order to achieve this, financial institutions need to establish systems that will enable them to know their customers well. This study deduces that there is a direct relationship between the personality traits and financial behaviours of investors. Among the various elements of personality traits, conscientiousness, agreeableness and openness to experience were found to be related to financial behaviour. Individual investors with different personality characteristics make different kinds of investments in line with their needs and exhibit different financial behaviours. Personality traits are a factor that financial institutions should focus on to establish a relationship between investor and investment products. Financial institutions should take into account the psychological characteristics of individual investors when designing their financial products. Financial advisors should advise individual investors to avoid fear of investment results that may arise from lack of information or other reasons. Financial advisors also should provide information to investors for developing financial strategies that are appropriate to investor's personalities.

\section{RECOMMENDATIONS}

Future research should take into account models of financial risk tolerance and financial behaviour that simultaneously investigate psychological and attitudinal factors.

\section{REFERENCES}

Alkaya, A. and Yagli, i. (2015). Financial Literacy-Financial Information, Behaviour and Attitude: An Application on Nevşehir Hacı Bektaş Veli University iiBF Students. Journal of International Social Research, 8(40).

Allgood, S. and Walstad, W. (2011). The effects of perceived and actual financial knowledge on credit card behaviour. Networks Financial Institute Working Paper. Indiana State University.

Anbar, A. and Eker, M. (2010). 'An Empirical Investigation for Determining of the Relationship Between Personal Fina ncial Risk Tolerance and Demographic Characteristic', Ege Academic Review. Vol. 10(2), 503-523.

Arifin, A. Z. (2017). The Influence of Financial Knowledge, Control and Income on Individual Financial Behaviour. European Research Studies, 20(3A), 635.

Asebedo, S. D. (2018). Personality and Financial Behaviour. Client Psychology, 137-153.

Asebedo, S. D., Wilmarth, M. J., Seay, M. C., Archuleta, K., Brase, G. L. and MacDonald, M. (2019). Personality and saving behavior among older adults. Journal of Consumer Affairs, 53(2), 488-519. 
Bajtelsmit, V. L. and Bernasek, A. (1996). Why do women invest differently than men? Financial Counseling and Planning, 7, 1-10.

Bernheim, B. D., Garrett, D. M., and Maki, D. M. (2001). Education and saving:: The long-term effects of high school financial curriculum mandates. Journal of public Economics, 80(3), 435-465.

Costa FT Jr, McCrae RR, Dye DA. (1991). Facet scales for agreeableness and conscientiousness: A revision of the NEO Personality Inventory. Personality and Individual Differences, 12,887-898.

Costa, P. T. and McCrae, R. R. (1992). Revised NEO personalityinventory (NEO-PIR): Professional manual. Odessa, FL: Psychological Assessment Resources.

Davey, J. and George, C. (2011). Personality and Finance: The Effects of Personality on Financial Attitudes and Behaviour. International Journal of Interdisciplinary Social Sciences, 5(9).

Digman, J. M. (1990). Personality structure: Emergence of the five-factor model. Annual review of psychology, 41(1), 417-440.

Donnelly, G., Iyer, R. and Howell, R. T. (2012). The Big Five personality traits, material values, and financial well-being of self-described money managers. Journal of Economic Psychology, 33(6), 1129-1142.

Dwyer, P. D., Gilkeson, J. H. and List, J. A. (2002). Gender differences in revealed risk taking: evidence from mutual fund investors. Economics Letters, 76, 151-158. http://dx.doi.org/10.1016/S0165-1765(02)00045-9

Erkus, A. and Tabak, A. (2009). Effects of Five Factor Personality Traits on Conflict Management Styles of Employees: Research in Industry. Ataturk University Journal of Economics \& Administrative Sciences, 23(2).

Goldberg, L. R. (1990). An alternative" description of personality": the big-five factor structure. Journal of personality and social psychology, 59(6), 1216.

Gong, B. and Yang, C. (2012). Gender differences in risk attitude: Field experiments on the matrilineal mosuo and the patriarchal yi. Jour nal of Economic Behavior \& Organization, 83, 59-65. http://dx.doi.org/10.1016/j.jebo.2011.06.010

Grable, J. E. and Joo, S. (2004). Environmental and biopsychosocial factors associated with financial risk tolerance. Financial Counseling and Planning, 15(1), 73-82.

Grable, J. E. and Lytton, R. H. (1998). Investor risk tolerance: Testing the efficacy of demographics as differentiating and classifying factors. Financial Counseling and Planning, 9(1), 61-74.

Grable, J. E. and Joo, S. H. (2000). A cross-disciplinary examination of financial risk tolerance. Consumer Interests Annual, 46, $151-157$.

Hallahan, T. A., Faff, R. W. and McKenzie, M. D. (2004). An empirical investigation of personal financial risk tolerance. Financial Services Review, 13, 57-78

Heo, W.,Nobre, L. H. N., Grable, J. E. and Ruiz-Menjivar, J. (2016). What Role Does Financial Risk Tolerance Play in Mediating Investing Behaviour? Journal of Financial Service Professionals, 70(5), 42-52.

Hershey, Douglas A. and Mowen, John C.. (2000). Psychological Determinants of Financial Preparedness for Retirement. The Gerontologist, 40 (6): 687-697.

Hilgert, M. A.,Hogarth, J. M., and Beverly, S. G. (2003). Household financial management: The connection between knowledge and behaviour. Fed. Res. Bull.,89, 309.

Ibrahim, M. E. and Alqaydi, F. R. (2013). Financial literacy, personal financial attitude, and forms of personal debt among residents of the UAE. International Journal of Economics and Finance, 5(7), 126

Jamshidinavid, B., Chavoshani, M., and Amiri, S. (2012). The impact of demographic and psychological characteristics on the investment prejudices in Tehran stock. European Journal of Business and Social Sciences, 1(5), 41-53.

Jianakoplos, N. A., and Bernasek, A. (2006). Financial risk taking by age, and birth cohort. Southern Economic Journal, 72(4), $981-1001$. http://dx.doi.org/10.2307/20111864

Judge, T. A., Higgins, C. A., Thoresen, C. J. and Barrick, M. R. (1999). The big five personality traits, general mentalability, and career success across the life span. Personnel psychology, 52(3), 621-652.

Kotlikoff, L. and Bernheim, B. (2001). Household financial planning and financial literacy in Essays on saving, bequests, altruism, and life-cycle planning.

Kowert, P. A. and Hermann, M. G. (1997). Who takes risks? Daring and caution in foreign policy making. Journal of conflict Resolution, 41(5), 611-637.

Kubilay, B. and Bayrakdaroglu, A. (2016). An empirical research on investor biases in financial decision-making, financial risk tolerance and financial personality. International Journal of Financial Research, 7(2), 171. 
Lan, Q., Xiong, Q., He, L. and Ma, C. (2018). Individual investment decision behaviors based on demographic characteristics: Case from China. PloS one, 13(8), e0201916.

Larkin, C., Lucey, B. M. and Mulholland, M. (2013). Risk tolerance and demographic characteristics: Preliminary Irish evidence. Financial Services Review, 22, 77-91.

Lusardi, A. (2008). Household saving behaviour: The role of financial literacy, information, and financial education programs (No. w13824). National Bureau of Economic Research.

Mayfield, C., Perdue, G. and Wooten, K. (2008). Investment management and personality type. Financial Services Review, 17(3), $219-236$.

McCrae, R. R. and John, O. P. (1992). An introduction to the five-factor model and its applications. Journal of personality, 60(2), $175-215$.

McCrae, R. R. and Costa, P. T. (1997). Conceptions and correlates of openness to experience. In Handbook of personality psychology. London: AcademicPress.

Nga, J. K. and Ken Yien, L. (2013). The influence of personality trait and demographics on financial decision making among Generation Y. Young Consumers, 14(3), 230-243.

Oehler, A.,Wendt, S., Wedlich, F. and Horn, M. (2018). Investors' personality influences investment decisions: Experimental evidence on extraversion and neuroticism. Journal of Behavioural Finance, 19(1), 30-48.

Pak, O. and Mahmood, M. (2015). Impact of personality on risk tolerance and investment decisions: A study on potential investors of Kazakhstan. International Journal of Commerce and Management, 25(4), 370-384.

Perry, V. G. and Morris, M. D. (2005). Who is in control? The role of self-perception, knowledge, and income in explaining consumer financial behaviour. Journal of Consumer Affairs, 39(2), 299-313.

Pinjisakikool, T. (2018). Thelnfluence of Personality Traits on Households' Financial Risk Tolerance and Financial Behaviour. Journal of Interdisciplinary Economics, 30(1), 32-54.

Potrich, A. C. G.,Vieira, K. M. and Mendes-Da-Silva, W. (2016). Development of a financial literacy model for university students. Management Research Review, 39(3), 356-376.

Powell, M. and Ansic, D. (1997). Gender differences in risk behaviour in financial decision-making: An experimental analysis. Journal of Economic Psychology, 18, 605-628. http://dx.doi.org/10.1016/S0167-4870(97)00026-3

Raheja, S. and Dhiman, B. Does Investor Personality Determine their Risk Tolerance?

Roszkowski, M. J. and Grable, J. E. (2005). Estimating risk tolerance: The degree of accuracy and the paramorphic representations of the estimate. Financial Counseling and Planning, 16(2), 29-47.

Soane, E., Dewberry, C. and Narendran, S. (2010). The role of perceived costs and perceived benefits in the relationship between personality and risk-related choices. Journal of Risk Research, 13(3), 303-318.

Tauni, M. Z.,Rao, Z. U. R., Fang, H., Mirza, S. S., Memon, Z. A. and Jebran, K. (2017). Do investor's Big Five personality traits influence the association between information acquisition and stock trading behaviour?.China Finance Review International, 7(4), 450-477.

Unal, S. and Duger, Y. S. (2015). An empirical study of the relationship between the financial trait of academic staff and the trend of financial behaviour.

Wang, H. and S. Hanna, 1997. “Does Risk Tolerance Decrease with Age? Financial Counseling and Planning 8(2), pp. 27-32.

Watson, D. and Clark, L. A. (1997). Extraversion and its positive emotional core. In Handbook of personality psychology (pp. 767-793).

Zaidi, F. B. and Tauni, M. Z. (2012). Influence of investor's personality traits and demographics on overconfidence bias. Institute of Interdisciplinary Business Research, 4(6), 730-746.

Zhao, H. and Seibert, S. E. (2006). The big five personality dimensions and entrepreneurial status: A meta-analyticalreview. Journal of Applied Psychology, 91(2), 259-271. 
Appendix 1: Results of Factor Analysis

\begin{tabular}{|c|c|c|c|c|c|c|}
\hline Expressions & 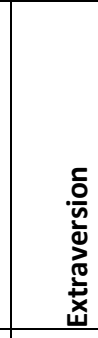 & 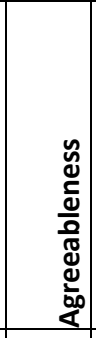 & 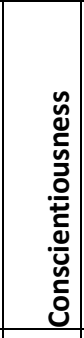 & 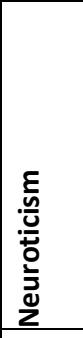 & 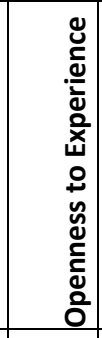 & 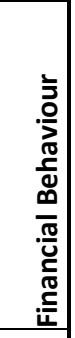 \\
\hline I'm a cheerful person & 0.695 & & & & & \\
\hline I feel very comfortable myself in the community. & 0.673 & & & & & \\
\hline I like to talk to strangers. & 0.571 & & & & & \\
\hline I always start chats. & 0.793 & & & & & \\
\hline I describe myself as extroverted. & 0,532 & & & & & \\
\hline I like to be in the foreground. & 0,709 & & & & & \\
\hline I make an effort to draw attention. & 0,672 & & & & & \\
\hline It makes me happy to be the center of attention. & 0,713 & & & & & \\
\hline I understand people's feelings and troubles. & & 0.680 & & & & \\
\hline I take care of people. & & 0.876 & & & & \\
\hline I take time for others & & 0.856 & & & & \\
\hline I can feel others' feelings. & & 0,837 & & & & \\
\hline I get along with people. & & 0,679 & & & & \\
\hline I'il make people feel better. & & 0,683 & & & & \\
\hline I make people relax & & 0,571 & & & & \\
\hline I fulfill my responsibilities on time. & & & 0.895 & & & \\
\hline I'm always ready to take responsibility. & & & 0.798 & & & \\
\hline I'm careful about the details. & & & 0.676 & & & \\
\hline I work programmed to fulfill my responsibilities. & & & 0.850 & & & \\
\hline I'm meticulous about my work. & & & 0.857 & & & \\
\hline I take responsibility in my job. & & & 0,648 & & & \\
\hline I don't run out of my responsibilities. & & & 0,772 & & & \\
\hline I enjoy fulfilling my responsibilities under all circumstances. & & & 0,804 & & & \\
\hline I'm usually responsible. & & & 0,853 & & & \\
\hline I'm easily stressed. & & & & 0.786 & & \\
\hline My mood is very variable. & & & & 0.783 & & \\
\hline I'm easily upset. & & & & 0.618 & & \\
\hline I'm just angry. & & & & 0.804 & & \\
\hline I often feel sad. & & & & 0.707 & & \\
\hline I'm easily disturbed. & & & & 0.762 & & \\
\hline I love trying new things. & & & & & 0.727 & \\
\hline I'm interested in new ideas. & & & & & 0.684 & \\
\hline I would like to be the first to try new products. & & & & & 0.897 & \\
\hline I'm not afraid to try new things. & & & & & 0.885 & \\
\hline
\end{tabular}




\begin{tabular}{|c|c|c|c|c|c|c|}
\hline I'm open to new ideas. & & & & & 0,675 & \\
\hline I save money. & & & & & & 0.777 \\
\hline I know how I will pay when I use a credit card. & & & & & & 0.753 \\
\hline I set long-term financial goals that affect my spending. & & & & & & 0.689 \\
\hline I pay my credit cards on time to avoid paying extra fees. & & & & & & 0.677 \\
\hline I plan my financial future. & & & & & & 0.795 \\
\hline I keep my expenditures under control. & & & & & & 0.807 \\
\hline I check my credit card accountability for possible errors and debts. & & & & & & 0,740 \\
\hline I save money on a monthly basis. & & & & & & 0,763 \\
\hline Before big purchases, I analyze my financial situation. & & & & & & 0,725 \\
\hline Cronbach's Alphas & 0,836 & 0,881 & 0,933 & 0,845 & 0,861 & 0,897 \\
\hline
\end{tabular}

